\title{
Technical and Financial Feasibility of a Stand-alone Photovoltaic System for Rural Electrification in the Andean South Region of Peru
}

\author{
Karen S. Villanueva Saberbein ${ }^{1} \& \mathrm{Lu}_{\mathrm{Aye}}{ }^{1}$ \\ ${ }^{1}$ Renewable Energy and Energy Efficiency Group, Department of Infrastructure Engineering, University of \\ Melbourne, Victoria, Australia \\ Correspondence: Lu Aye, Department of Infrastructure Engineering, University of Melbourne, Victoria 3010, \\ Australia. Tel: 61-3-8344-6879. E-mail: lua@unimelb.edu.au
}

Received: October 3, 2012 Accepted: October 24, 2012 Online Published: October 26, 2012

doi:10.5539/jsd.v5n11p32

URL: http://dx.doi.org/10.5539/jsd.v5n11p32

\begin{abstract}
The Andean South is one of the poorest regions of Peru. Only $44 \%$ of the rural inhabitants of this area have electricity. This paper describes an investigation into the technical and financial feasibility of stand-alone photovoltaic systems in this region. The feasibility study was undertaken for a typical village of Andean South. The village of Churrubamba Alta in the province of Andahuaylas, departamento de Apurimac (department of Apurimac) was selected. The TRNSYS software tool was used for performance analysis and identifying the optimal size of the system. The feasibility study showed that the best option is a $13.7 \mathrm{~kW} \mathrm{PV}$ array and $180 \mathrm{kWh}$ battery bank for the daily supply of $42.2 \mathrm{kWh}$ electricity to 62 households and a community centre. The financial analysis demonstrated a net present value of US\$186 918, internal rate of return of $28 \%$, payback period of 4.3 years and levelised cost of electricity of US $\$ 0.30$ per $\mathrm{kWh}_{\mathrm{e}}$.
\end{abstract}

Keywords: photovoltaic, stand-alone power, solar mini-grid, rural electrification, Andean South, TRNSYS

\section{Introduction}

\subsection{Renewable Energy Resources for Rural Electrification}

Energy is recognised as a crucial driving force for human well-being and a country's economic development. Humans use energy in different forms in almost every facet of their lives. One type of supply energy is electricity which is the most widely used and is expected to grow rapidly in the coming years. About 1.3 billion people do not have access to electricity and $84 \%$ of them are in rural areas (International Energy Agency [IEA], 2011). In rural areas of developing countries, electricity is used mainly for two purposes, residential and small-scale productive uses (Cabraal, Barnes, \& Agarwal, 2005). Rural electrification is the key to promote better quality education, income, health and social development of poor areas (Mathur \& Mathur, 2005).

The lack of access to electricity in developing countries is a result of the characteristics of rural areas. One common pattern is the low and varying amount of electricity consumption between inhabitants of the same village. While a few households may consume large amounts of electricity, the majority consume small amounts. Moreover, there is little data about rural energy consumption which increases the complexity in the energy system modelling for rural areas (Morante \& Zilles, 2008). Strong dependence on centralized energy systems and the high investment required for transmission and distribution grids increases the cost of delivering electricity, making it unaffordable for rural inhabitants. In order to make electricity affordable and accessible, it is important to explore alternative power generation and distribution systems. Decentralized systems are mostly based on renewable energy sources which operate at a smaller scale and are easily accessible to remote locations (Kaundinya, Balachandra, \& Ravindranath, 2009).

Decentralised systems for residential rural electrification can be classified into home systems and mini-grids. When installing home systems in remote areas, they normally have the same power capacity for every household. However, the architecture of the house, social, economic, cultural and education level differentiate the behaviour of the energy consumption between households (Morante \& Zilles, 2008). On the other hand, mini-grids allow supply of different amounts of electricity to the households of the same area. Nevertheless, some studies suggest that mini-grids are not economically viable unless a small industry (carpentry, welding, crop drying, sewing, 
water pumping, desalination, health and leisure services) is connected (Martinot, Chaurey, Lew, Moreira, \& Wamukonya, 2002).

Traditionally, mini-grids for rural electricity are based on diesel engine or small hydropower plants. A reduced number of installed mini-grids are based on wind energy conversion systems (WECS), photovoltaic (PV) panels and hybrid systems. These technologies have not experienced rapid adoption due to high upfront costs in comparison with diesel engine mini-grids. However the cost of PV and WECS are decreasing while increasing system efficiency (Martinot et al., 2002).

\subsection{Rural Electrification in Peru}

Since 1990, Peru has adopted neo-liberal market reforms in the electricity sector. With the introduction of the Law of Electric Concessions, the electricity coverage increased rapidly from $57 \%$ in 1993 to $82 \%$ in 2010 (Direccion General de Electrificacion Rural [DGER], 2010). However, this growth was concentrated in the urban areas (Cherni \& Preston, 2007). This is a reflection of the inequalities present in Peru. The wealth and western modernisation is located mainly along the coast of the country. In contrast, the Amazonian and Andean regions, where the majority of the population is indigenous and live in rural areas, have been neglected for several decades.

The national rural electrification coverage has grown from $7.7 \%$ in 1993 to $55 \%$ in 2010 . This low electricity coverage is a result of the conditions of the rural areas such as inaccessibility of villages, reduced unit consumption, scattered homes and households' low purchasing power. In addition, in rural areas, road, health, education, sanitation, housing and agricultural infrastructure are low or nonexistent. The combination of these factors has resulted in the isolation of the rural population and economic infeasibility of centralised grid electricity projects (DGER, 2010).

In 2002, the government introduced the Law for Rural Electrification (LRE) as a result of the failure to increase electrification coverage in rural areas. However, this law and the consequent "National Plan for Rural Electrification" (Plan Nacional de Electrificación Rural [PNER]) have been criticised by different stakeholders for the absence of a strategic approach (Cherni \& Preston, 2007). The LRE set the starting point to deliver feasible projects for rural electrification. The LRE declared rural electrification to be a 'national necessity' and the use of renewable energy resources to be in the 'national interest'. Neither the LRE nor PNER fixed a specific target for renewable energy in the energy mix of new projects. However, the selection criterion for rural electrification projects provides the highest ranking to projects based on renewable energy.

\subsection{Rural Electrification in the Andean South}

The Andean South region is located from $12.05^{\circ}$ to $18.38^{\circ}$ latitude south and $68.54^{\circ}$ and $75.99^{\circ}$ longitude west (Servicio Nacional de Meteorologia e Hidrologia [SENAMHI] \& Ministerio de Energia y Minas [MEM], 2003). It includes the Departments of Huancavelica, Ayacucho, Cuzco, Apurímac and Puno. This region is the second poorest in Peru after the Andean North. The economy of the region is based mostly on subsistence agriculture where the main crop is potato. More than half of the population (55\%) lives in rural households of which nearly $70 \%$ are poor, and about $38 \%$ are extremely poor. The monthly expenditure for an average rural Andean South household is US\$108 (S/.292) (S/. = Peruvian Nuevo Soles) while the average rural national expenditure is US\$179 (S/.482). The poorest region, Andean North, has an average rural household expenditure of US\$100 (S/.271) (Meier, Tuntivate, Barnes, Bogach, \& Farchy, 2010).

The percentage of rural households with access to electricity in the Andean South is 44\% (Meier et al., 2010). This coverage ratio can be increased by using renewable energies in isolated areas where the grid extension is not financially feasible. The Andean South has several renewable energy resources such as solar, wind and hydro. The Andean South is the region with the highest available solar radiation over Peruvian Andes averaging 5.5-6.0 $\mathrm{kWh} / \mathrm{m}^{2}$ (SENAMHI \& MEM, 2003). The available wind energy varies in this region. While in Apurimac the average wind speed is between 2-3 m/s over the year, Puno has an average wind speed between 4-5 m/s (MEM \& World Bank - Global Environment Fund [WB-GEF], 2003).

In rural Peru, mini-grids mainly based on hydropower and diesel generators have been implemented (Williams \& Simpson, 2009). Home systems based on PV-battery and WECS-battery have also been installed in remote villages (Cherni \& Preston, 2007). In a rural electrification project in Cajamarca, a combined system based on individual and micro-grids, WECS were proven to be the most efficient (Ferrer-Martí, Garwood, Chiroque, Escobar, \& Coello, 2010).

The aim of this paper is to assess the technical and financial feasibility of rural electrification projects based on stand-alone photovoltaic systems for the Andean South region of Peru. According to the literature accessible to 
date, no stand-alone photovoltaic mini-grid has been installed to provide electricity to poor rural inhabitants in Peru. Moreover, the subsidies provided by the Peruvian government do not include stand-alone mini-grids. Subsidies are not provided due to the limited experience of the World Bank with this type of project and lack of research on this topic in Peru. It should be noted that the World Bank is one of the major stakeholders in the development of the subsidy strategies for rural electrification in Peru.

\section{Method}

A major task in the design is the optimisation of the system size to minimise the life cycle cost. With an optimum set of components, the system may be able to compete financially with conventional technologies, such as a small diesel generator mini-grid or the extension of the national grid. Using a bottom-up approach, the first step is the selection of a typical locality in the Andean South region. All the steps required to evaluate the feasibility of this system in the Andean South are studied using this representative locality. The evaluation can be divided into two parts: the technical analysis and the financial analysis. For this study, a village was selected using the Geographic Information System of the Peruvian National Plan for Rural Electrification (DGER, 2012). This system provides information about rural villages classified according to their status of electrification. The system provides geographic coordinates and the number of households for every village.

\subsection{Technical Analysis}

The first task was the assessment of the renewable energy resources at the site using reliable meteorological data. Then the electricity demand was determined based on the peak power consumption and daily total load. The renewable energy resources and the electricity consumption were the input for the selection of the system components under a specific system configuration. A parametric method was used to provide a starting point for the simulation of the energy system. TRNSYS simulates the system performance for different system sizes and component specifications. Finally, the optimum size for the system was found through the minimisation of a function using GenOpt ${ }^{\circledR}$, a computer tool compatible with TRNSYS. The objective function was the life cycle cost (LCC) of the main system components. Constraints were also considered.

\subsubsection{Computer Software Tool}

TRNSYS was used for the simulation and GenOpt ${ }^{\circledR}$ was used for the optimisation of the system. Table 1 shows the various TRNSYS components used in this project. For detailed mathematical descriptions, the reader may refer to TRNSYS 16 User Manual (Klein et al., 2006).

Table 1. TRNSYS components

\begin{tabular}{ll}
\hline Main components & Auxiliary components \\
\hline Type 54a - Hourly Weather Data Generator & Type 9a - Generic Data Files \\
Type 16c - Radiation Processors & Type 57 - Unit Conversion Routine \\
Type 94a - Photovoltaic Panels & Type 24 - Quantity Integrator \\
Type 47a - Batteries & Type 65d - Online Plotter \\
Type 48b - Regulators and Inverters & Type 25 - Printer \\
& TRNOPT - Optimisation Program Interface \\
\hline
\end{tabular}




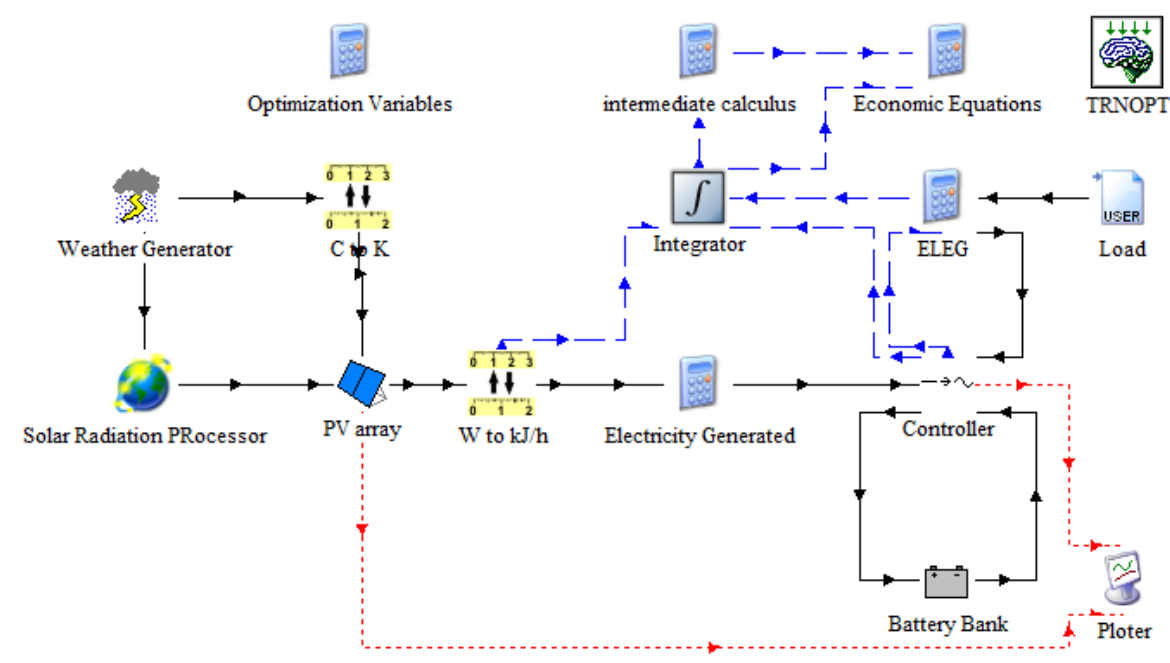

Figure 1. Stand-alone photovoltaic system modelled in TRNSYS

\subsubsection{Meteorological Data}

Meteorological data is collected by the Peruvian National Service of Meteorology and Hydrology (Servicio Nacional de Metereología e Hidrología del Perú [SENAMHI], 2012). However, long-term measured or reliable synthetic data for solar energy is not available for every locality of Peru (Gansler, Klein, \& Beckman, 1994). This information is mostly available only for main coastal cities and airports.

Another source of reliable meteorological data can be found on the webpage of the Prediction of Worldwide Energy Resource Project of the National Aeronautics and Space Administration [NASA] (2012). The meteorological information available is the monthly average of 22 years of satellite measurements. Peruvian institutions have developed a Solar Atlas for the country (MEM \& WB-GEF, 2003; SENAMHI \& MEM, 2003). This document was used to check the reliability of the data obtained from NASA.

The design of systems using renewable energy requires hourly data for simulation to obtain better assessment of the system size than the rule-of-thumb method (Zhou, Lou, Li, Lu, \& Yang, 2010). The generation of hourly data from the monthly average values obtained from NASA was done using the Type 54-Weather Generator. The selection of the slope that maximises the solar power generation from the photovoltaic panel is an important parameter for a PV system. The slope that maximises the power output over the year produced by the PV panel is similar to the latitude angle of the site (Grainger, 1990). The optimal value for the slope was identified using $\mathrm{GenOpt}^{\circledR}$.

\subsubsection{Typical Annual Load Profile for the Project}

The load profile can be obtained through national statistics, studies or surveys. When no reliable statistics are available, it is necessary to make assumptions and calculations. In order to obtain figures of the studied settlement, the first step was to consult the last national census (Instituto Nacional de Estadisticas e Informatica [INEI], 2007). Formal studies about the electricity consumption in the studied location, like the one performed by Meier et al. (2010), were also taken into consideration. The electricity required depends on the type of appliances that are connected and their duty period. From this information, the peak power and load profile were estimated. The peak load was estimated using the average consumption for electric appliances in Peru (MEM 2012) and electrical appliances existing in South Andean households (Meier et al., 2010). The assumption on hours of service and load trend was made by referencing similar rural electrification projects (Casillas \& Kammen, 2011; Dimas, Gillani, \& Ans, 2011; Mondal \& Denich, 2010).

Mini-grids become more financially attractive when productive uses of electricity are considered. Following the initiative of the European Commission's EuropeAid Co-operation Office which implemented stand-alone hybrid wind-solar-battery systems in 130 localities of Peru (EURO-SOLAR, 2012), the project assumed that there are five laptops with internet access, a projector, vaccine refrigerator and water purifier at a community centre. The community centre is expected to operate 12 hours per day.

The electricity consumptions of the households and community centre were aggregated and entered into TRNSYS by using Type 9 - Data Reader. This component reads data at a regular time intervals making it 
available for other TRNSYS components (Klein et al., 2006). An equation unit is added to the model to multiply the load by 1.10 . This is done since the system loss in the distribution lines was estimated to be $10 \%$ (MEM, 2011). In consequence, the peak load is also increase by $10 \%$.

\subsubsection{System Description}

The system distributes and supplies to the consumers in single phase AC $220 \mathrm{~V}, 60 \mathrm{~Hz}$ (the standard electric power supply in Peru). The system is designed to deliver AC electricity since there is a greater range of inexpensive AC domestic appliances available and to facilitate a potential future grid connection. The AC electricity is delivered in a single phase since there are not expected to be many energy-intensive appliances. The photovoltaic array generates DC electricity which is stored in the battery bank. The PV panels are connected through the battery charger. The system controller works also as an inverter. The components of the system were selected from the available range of national and international brands offered in the current Peruvian market.

\subsubsection{Pre-sizing of the System}

The final component sizes are the result of the optimisation process. However, it is convenient to start the optimisation with values of variables which are close to the optimal. This is made in order to speed up the convergence time. Different system configurations were simulated to visualise the cost of the system under different amounts of load sharing by the PV array and battery bank. The methodology for the pre-sizing is described in Kishore (2009). Using the equations provided, the battery bank was sized for two, three and four days of autonomy. Life cycle cost (LCC) for the system was then calculated for the different system configurations. At this stage, the LCC was evaluated for 18 years. The results of the LCC analysis provided the limits of the variables for the optimisation study.

\subsubsection{Optimisation}

The sizing of the PV system can be regarded as an optimisation problem based on the cost of the project and power reliability (Zhou et al., 2010). The selected objective function for this study is the LCC which considers the capital cost plus the annualised cost of operation and maintenance required throughout the lifetime of the project. The power reliability is handled as a constraint.

Based on Yang, Zhou and Lou (2009), the LCC function to determine the optimal configuration of the stand-alone photovoltaic energy system includes the sizes of the PV array and the battery bank. The LCC was calculated using Equation 1.

$$
\sum_{n=1}^{N} K_{n}+\sum_{y=1}^{Y} \sum_{n=1}^{N} O \& M_{n, y}+\sum_{y=1}^{Y} \sum_{n=1}^{N} R_{n, y}+g(\vec{x})
$$

where $K_{n}$ is the capital cost (in US\$) of the component $n, O \& M_{n, y}$ is the annualized operation and maintenance cost of the component $n$ in the year $y$, and $R_{n, y}$ is the annualized replacement cost of the component $n$ in the year $y, g(\vec{x})$ is the constraint of the objective function.

The objective function includes a constraint in the equation to ensure the energy supply for the hourly energy demand of the project and is calculated using Equation 2.

$$
g(\vec{x})=\sum_{y=1}^{Y} \sum_{h=1}^{H} L_{h, y}-\sum_{y=1}^{Y} \sum_{h=1}^{H} \sum_{n=1}^{N} G_{n, h, y}<0
$$

where $L_{h, y}$ is the hourly required electricity and $G_{n, h, y}$ is the hourly generated electricity in the component $n$ in the hour $h$ in the year $y$ respectively.

The optimisation algorithm used to evaluate discrete and continuous variables in $\mathrm{GenOpt}^{\circledR}$ was the Particle Swarm Optimisation (PSO) (Wetter, 2008). The topology selected is von Newman, 3 particles, 200 generations, seed 0 , cognitive acceleration constant of 2.8 , social acceleration constant of 1.3 and velocity clamping with a maximum velocity gain of 0.5 . The variation used is the PSO with constriction coefficient with a constriction gain of 0.5 (Boonbumroong, Pratinthong, Thepa, Jivacate, \& Pridasawas, 2011).

The variables to be optimised in this study are the number of PV panels and the battery bank capacity. GenOpt ${ }^{\circledR}$ permits discrete or continuous variables in the optimisation. The number of PV panels corresponds to a discrete variable and the battery bank capacity to a continuous variable. The battery bank was specified as a continuous variable since there are a variety of batteries with different capacities available in the market. 


\subsection{Financial Analysis}

An analysis is also required to determine the financial feasibility of this energy project. The financial analysis includes the revenue from the collection of the electricity charges to the system users, the analysis of the LCC of the entire system, Net Present Value (NPV) and Levelised Cost of Electricity (LCOE). The NPV and the LCOE are evaluated for 25 years. The time horizon of 25 years was selected for the evaluation since this is the assumed lifetime of the PV panel, inverter, battery charger and controller of the system. The lifetime of the batteries was assumed to be 18 years.

\subsubsection{Revenue Analysis}

The price of electricity for the consumers considered in this project corresponds to the Rural Electricity Tariff for Photovoltaic Systems BT8-240 available from May $4^{\text {th }}$, 2012. The current tariff for users without subsidy is US $\propto 174$ per $\mathrm{kWh}_{\mathrm{e}}$. The discounted tariff for users including the subsidy is US $\$ 35$ per $\mathrm{kWh}_{\mathrm{e}}$ (Organismo Supervisor de la Inversion en Energia y Mineria [OSINERGMIN], 2012). The community centre is expected to be self-sufficient. This means that a reduced tariff will be charged for the use of the facilities. However, the investment cost analysis and operation, maintenance and management of the community centre are beyond the scope of this study.

\subsubsection{Life Cycle Cost Analysis}

The LCC considers the investment cost, O\&M and the replacement costs. The investment cost of this project comprises the costs of the PV array, the battery bank, the battery charger, the controller, wiring and additional components. For this study, the costs of the wiring and additional components were assumed to be $10 \%$ of the cost of other components (PV array, battery bank, battery charger and controller). The investment cost generally includes the cost of the equipment plus the installation cost and any modification required in the equipment (Duffie \& Beckman, 2006). The cost of the system installation and other modification required was assumed to be $10 \%$ of the sum of the main components. According to Duffie and Beckman (2006), the annual cost of an energy system includes fuel expenses, mortgage payments, maintenance and insurance, parasitic energy costs, property taxes minus the income tax savings. In this project, the only annual cost considered is the maintenance of the system.

\subsubsection{Net Present Value}

The NPV is one of the most comprehensive approaches for the financial evaluation of a project. The NPV method evaluates the future cash flows of the system in a real value basis. This is done by discounting the cash flows at a specific interest rate. In addition, the recurrent costs of the project can be assumed to inflate or deflate at a fixed inflation rate (Duffie \& Beckman, 2006). This study assumed an interest rate of $10 \%$ in line with IEA. The IEA argues that a lower rate would lead to significantly lower estimates for generation costs (IEA, 2010). The inflation rate selected for the project is $2.5 \%$. It was taken from the Peruvian Survey on Macroeconomic Expectations of Inflation (INEI, 2012). The NPV was calculated using Equation 3.

$$
N P V=\sum_{y=1}^{Y} \frac{C F(1+i)^{y}}{(1+d)^{y}}
$$

where $C F$ is the annual cash flow for the year $y, i$ is the interest rate and $d$ is the discount rate.

Two additional parameters derived from the NPV were also evaluated for this project. They are the internal rate of return (IRR) and the payback period. The IRR is used to measure and compare the profitability of the project. The IRR on a project is the annualised compounded return rate that makes the NPV of all cash flows from a project equal to zero. The payback period definition considered in this study is the time needed for the yearly cash flow to become positive (Duffie \& Beckman, 2006).

\subsubsection{Levelised Cost of Electricity}

The LCOE is an abstraction from reality and is used as a benchmark or ranking tool to assess the cost-effectiveness of different generation technologies. The method considers the lifetime generated electricity and cost to estimate a price per unit of electricity generated. The method does not usually include risk and different actual financing methods available for the different technologies (Branker, Pathak, \& Pearce, 2011). For the purpose of this study, the electricity consumed was used in the LCOE assessment instead of the electricity generated. Since this is a stand-alone system, part of the energy produced that is not stored in the battery bank or supplied to the load is dumped. The LCOE was calculated using Equation 4. 


$$
L C O E=\frac{\sum_{y=0}^{Y} L C C_{y}}{\sum_{y=0}^{Y} E_{y}}
$$

where $L C C_{y}$ is the life cycle cost in the year $y$ of the project considering the discount rate and the inflation rate and $E_{y}$ represent the energy produced in $\mathrm{kWh}_{\mathrm{e}}$ in the year $y$.

\section{Results and Discussion}

\subsection{Locality Selection}

A locality within the Department of Apurimac was selected. The electricity coverage ratio for Apurimac was 64.5\% in 2010 which was the second lowest ratio among other Departments of Peru. Moreover, it is predicted that Apurimac will be the Department with least electrification coverage (82.4\%) in 2020 (DGER, 2010). The selected village is Churrubamba Alta, in the district of Pacucha, in the province of Andahuaylas. This village has 62 households located at $13^{\circ} 37^{\prime}$ south latitude, $73^{\circ} 20^{\prime}$ west longitude at an altitude of $3719 \mathrm{~m}$ above the sea level.

\subsection{Meteorological Data}

The data obtained from NASA (2012) differed from the Geographic Information System of the PNER. The data was measured at an altitude of $3137 \mathrm{~m}$ above the sea level, which is about $700 \mathrm{~m}$ below Churrubamba Alta location. This meteorological data was compared with the Solar Atlas of Peru (MEM \& WB-GEF 2003) to evaluate its reliability. The meteorological data obtained from NASA are within the range of the Atlas. Measurement from NASA for daily average solar radiation over a year is $5.68 \mathrm{kWh} / \mathrm{m}^{2}$. The Solar Atlas range for daily average solar radiation over a year is between 5.5 and $6 \mathrm{kWh} / \mathrm{m}^{2}$. Solar energy resources available in Churrubamba Alta are abundant. The month with the minimum daily global radiation is June $\left(5.17 \mathrm{kWh} / \mathrm{m}^{2}\right)$ and the maximum month is August $\left(6.55 \mathrm{kWh} / \mathrm{m}^{2}\right)$. By using GenOpt ${ }^{\circledR}$, the optimum slope was found to be $14.78^{\circ}$ facing north. The hourly data is derived from the monthly data obtained from NASA by using TRNSYS Type 54a.

\subsection{Typical Annual Load Profile}

In the last national census, the locality of Churrubamba Alta had 62 households and no health services, primary or secondary schools (INEI, 2007) and there is only one kindergarten in the village. The closest site to obtain primary education and health services is Churrubamba which is located two $\mathrm{km}$ and $700 \mathrm{~m}$ lower than Churrubamba Alta and has no permanent availability of transport. The rural population in Apurimac is expected to shrink by $12 \%$ in the next ten years (INEI, 2007). However, it is expected that a community with access to electricity increases its education and the average household income levels (Meir et al., 2010), and in consequence, the electricity consumption. Thus, the future electricity demand was assumed to be same as the current electricity demand. The average Andean South rural household consumes $16.7 \mathrm{kWh}_{\mathrm{e}}$ per month, which is about half of the average electricity used by the average Peruvian rural household $\left(27.2 \mathrm{kWh}_{\mathrm{e}}\right.$ per month) (Meier et al., 2010). Table 2 provides the assumptions made and calculations used to determine the electricity load.

Table 2. Load assumptions and calculations for the households of Churrubamba Alta. Source: MEM (2012), Meier et al. (2010)

\begin{tabular}{ccccccc}
\hline Appliances & $\begin{array}{c}\text { Appliances' } \\
\text { owners [\%] }\end{array}$ & $\begin{array}{c}\text { Rated } \\
\text { power [W] }\end{array}$ & $\begin{array}{c}\text { No. of } \\
\text { appliances [-] }\end{array}$ & $\begin{array}{c}\text { Peak load } \\
{[\mathrm{kW}]}\end{array}$ & $\begin{array}{c}\text { Hours of } \\
\text { service }[\mathrm{h}]\end{array}$ & $\begin{array}{c}\text { Load } \\
{\left[\mathrm{kWh}_{e}\right]}\end{array}$ \\
\hline Lighting (x 3) & 100 & 15 & 186 & 2.79 & 4.0 & 11.16 \\
Radio & 64 & 10 & 40 & 0.40 & 2.0 & 0.80 \\
B\&W TV & 43 & 100 & 27 & 2.70 & 2.0 & 5.40 \\
Colour TV & 38 & 200 & 24 & 4.80 & 2.0 & 9.60 \\
Video/DVD & 8 & 200 & 5 & 1.00 & 1.5 & 1.50 \\
Iron & 14 & 1000 & 9 & 9.00 & 0.5 & 4.50 \\
Refrigerator & 4 & 150 & 2 & 0.30 & 6.0 & 1.80 \\
Total & & - & & 7.57 & - & 34.76 \\
\hline
\end{tabular}


The total daily consumption for the 62 households of the project was estimated to be $34.7 \mathrm{kWh}_{\mathrm{e}}$ and the peak load to be $7.57 \mathrm{~kW}$. Figure 2 shows the load profile for Churrubamba Alta households. It should be noted that the electricity consumption is concentrated in the evening. The assumptions and calculations made for the community centre's peak power consumption and daily consumption are presented in Table 3 . The daily total electricity usage in Churrubamba Alta for 62 households and one community centre is $42.2 \mathrm{kWh}_{\mathrm{e}}$ and the peak load is $8.34 \mathrm{~kW}$ (see Figure 4).

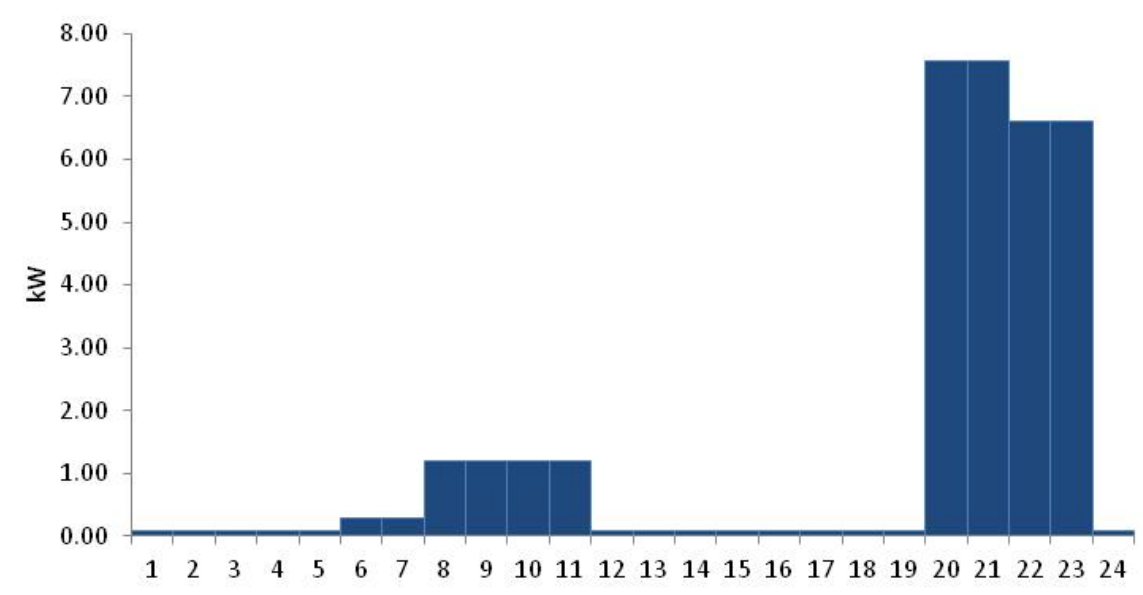

Figure 2. Households hourly load profile for the Churrubamba Alta households

Table 3. Load assumptions and calculations for the community centre of Churrubamba Alta. Source: MEM (2012); Meier et al. (2010)

\begin{tabular}{cccccc}
\hline & $\begin{array}{c}\text { Rated } \\
\text { power [W] }\end{array}$ & $\begin{array}{c}\text { No. of } \\
\text { Appliances [-] }\end{array}$ & $\begin{array}{c}\text { Peak load } \\
{[\mathrm{kW}]}\end{array}$ & $\begin{array}{c}\text { Hours of } \\
\text { service }[\mathrm{h}]\end{array}$ & $\begin{array}{c}\text { Load } \\
{\left[\mathrm{kWh}_{e}\right]}\end{array}$ \\
\hline Lighting & 15 & 5 & 0.075 & 3 & 0.23 \\
Refrigerator & 150 & 1 & 0.15 & 6 & 0.90 \\
PC & 200 & 5 & 1.00 & 6 & 6.00 \\
Projector & 150 & 1 & 0.15 & 6 & 0.90 \\
Water Purifier & 25 & 1 & 0.10 & 6 & 0.15 \\
Total & & & 0.78 & - & 8.18 \\
\hline
\end{tabular}

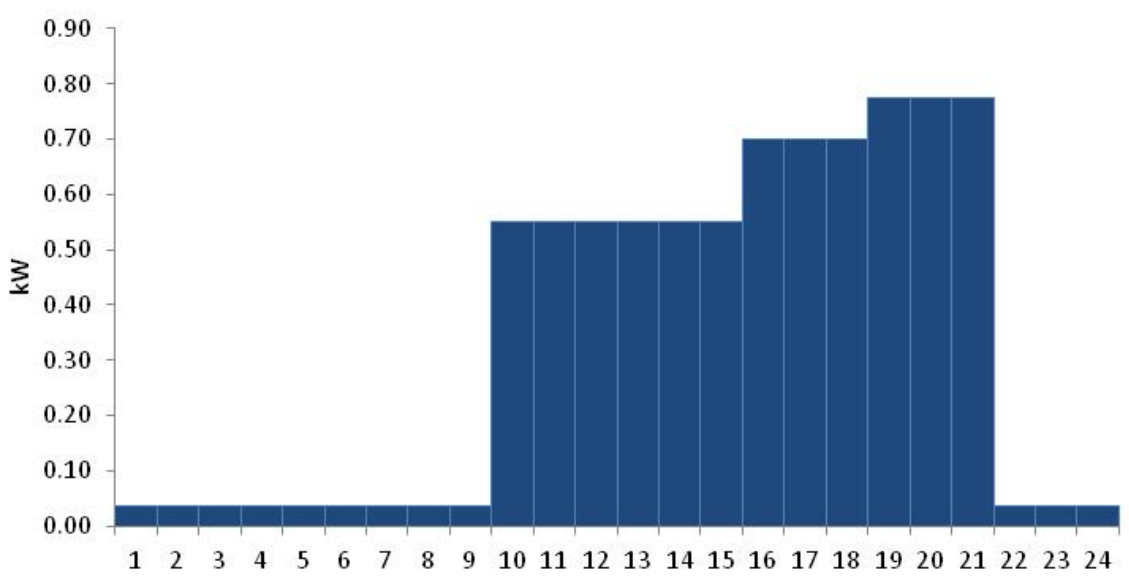

Figure 3. Community centre hourly load profile 


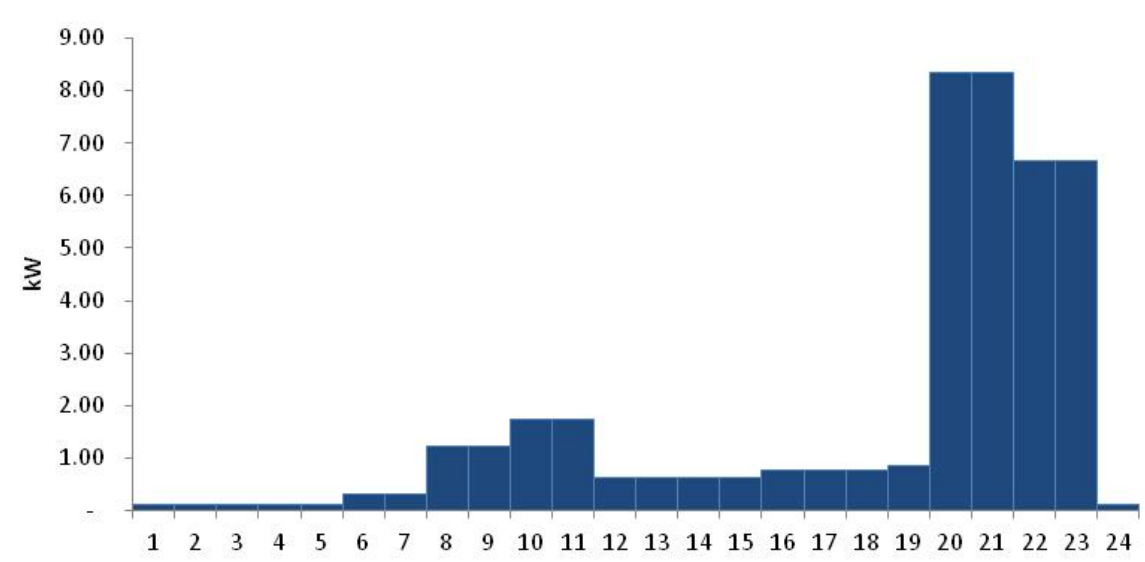

Figure 4. Total hourly load profile for 62 households and one community centre

\subsection{Pre-sizing of the System}

The battery bank capacity for two, three and four days of autonomy calculated using the equations from Kishore (2009) are $2687 \mathrm{Ah}, 4031 \mathrm{Ah}, 5375 \mathrm{Ah}$ respectively. The PV panel used for this project is a CNBM Solar Mono-crystalline Series II $240 \mathrm{Wp}$ (rated voltage $49 \mathrm{~V}$, rated current 4.9 A) at cost of US $\$ 2.8$ per Wp. The battery bank consists of lead-acid deep-cycle batteries at a cost of US\$147.5 per kWh. The simulation for 18 years demonstrated that the optimal value is closer to a battery bank storage for three days of autonomy (see Table 4).

Table 4. LCC for different days of autonomy and PV array/WECS load share for 18 years

\begin{tabular}{cccccc}
\hline $\begin{array}{c}\text { Days of } \\
\text { autonomy }\end{array}$ & $\begin{array}{c}\text { No. of PV } \\
\text { panels [-] }\end{array}$ & $\begin{array}{c}\text { PV array } \\
\text { cost [US\$] }\end{array}$ & $\begin{array}{c}\text { Battery bank } \\
\text { [US\$] }\end{array}$ & $\begin{array}{c}\text { PV and battery } \\
\text { O\&M [US\$] }\end{array}$ & $\begin{array}{c}\text { Total cost } \\
\text { [US\$] }\end{array}$ \\
\hline 2 & 68 & 45696 & 19024 & 11650 & 76370 \\
3 & 46 & 30912 & 28539 & 10701 & 70153 \\
4 & 44 & 29568 & 38055 & 12172 & 79795 \\
\hline
\end{tabular}

\subsection{Optimisation}

The pre-sizing narrows the range between the maximum and minimum values for the variables for the optimisation. The optimisation parameters for the number of PV panels and battery bank capacity are presented in Table 5. The optimum number of PV panels was found to be 47 and the optimum battery bank capacity to be $174.74 \mathrm{kWh}$, which corresponds to 2.7 days of autonomy. The LCC for this configuration was US\$67 682 . The simulation for this configuration showed an average battery state of charge of $77 \%$. At 2020 hour of the simulation time step the battery bank reaches its minimum allowable state of charge (20\%), which is set to avoid battery overheating and consequence shortened life (Patel, 2006).

The efficiency reduction after 25 years for the selected PV panel was assumed to be $20 \%$ (Liders, 2012). Thus, the number of PV panels required was incremented by $20 \%$. The final number of PV panels required is 57 (13.68 $\mathrm{kW}$ ). Batteries offered in the market are not available to provide the exact battery bank capacity found by the optimisation. The nearest higher battery bank capacity is $180 \mathrm{kWh}$ using 120 batteries of $750 \mathrm{Ah} 2 \mathrm{~V}$, which are readily available in the market. Table 6 presents the final optimal system size. Further details about the optimisation and the system components can be found in Villanueva-Saberbein (2012).

The use of the optimisation add-on for TRNSYS, GenOpt ${ }^{\circledR}$ helped to find an optimal size for the system in a reduced time. However, the selection of the constant value for the constraint in the objective function is a time-consuming manual process. As Wetter (2008) noted, the selection of a small value for the constant produces too big violation of the constraints and a large value can cause numerical problems. In this case, the TRNSYS- GenOpt ${ }^{\circledR}$ simulation was run ten times until the final stable value was found. 
Table 5. Optimisation variables

\begin{tabular}{cccc}
\hline \multicolumn{2}{c}{ Number of PV panels in parallel } & \multicolumn{2}{c}{ Total battery bank capacity } \\
\hline TRNSYS type & $94 \mathrm{a}$ & TRNSYS type & $47 \mathrm{a}$ \\
Parameter evaluated & No. of panels in parallel & Parameter evaluated & Total energy capacity \\
Type of variable & Discrete & Type of variable & Continuous \\
Panels in series & 1 & $2 \mathrm{~V}$ cells in series & 24 \\
Number of intervals & 3 & Step value & $12.0 \mathrm{kWh}$ \\
Start value index & 2 & Initial value & $174.7 \mathrm{kWh}$ \\
Minimum value & 44 & Minimum value & $168.0 \mathrm{kWh}$ \\
Maximum value & 48 & Maximum value & $180.0 \mathrm{kWh}$ \\
\hline
\end{tabular}

Table 6. Final system component sizes

\begin{tabular}{lll}
\hline Component & Units & Total capacity \\
\hline PV array & 57 & $13.68 \mathrm{~kW}$ \\
Battery charger & 2 & $13.72 \mathrm{~kW}$ \\
Controller & 2 & $10 \mathrm{~kW}$ \\
Battery & 120 & $180 \mathrm{kWh}$ \\
\hline
\end{tabular}

\subsection{Revenue Analysis}

The annual revenue from the 62 households and the community centre electricity usage was estimated to be US $\$ 26871$ where $80 \%$ of the annual revenue comes from the government subsidy. The households contribute $16 \%$ of the total income and the remaining $4 \%$ comes from the community centre. Including the subsidy, the community centre contributes $20 \%$ of the total revenue. This community use of electricity favours the financial feasibility of the mini-grids.

\subsection{Life Cycle Cost Analysis}

The investment cost for the PV panels for this project was quoted by Peruvian distributors (Alegre, 2012, pers. comm., 12 May 2012; DeltaVolt, 2012). The price for the battery charger is US $\$ 650$, based on the similar equipment available in the Peruvian market (ProViento, 2012). According to Patel (2006), the price of an inverter varies in relation to its nominal capacity. An inverter with a capacity up to $1 \mathrm{~kW}$ costs about US\$1500 per $\mathrm{kW}$, for inverters from 1 to $10 \mathrm{~kW}$ the cost is US\$1 000 per $\mathrm{kW}$, inverters from 10 to $100 \mathrm{~kW}$ cost US\$600 per $\mathrm{kW}$ and inverters up to $1 \mathrm{MW}$ is US $\$ 400$ per $\mathrm{kW}$. These costs were considered for the selected controller. The total investment cost of the system is US\$92 146 where $70 \%$ of this corresponds to the PV array and the battery bank (Table 6). The O\&M cost considered in this research project is $1 \%$ of the PV system investment cost per year (IEA 2010). The annual O\&M cost for the system is US\$921. The replacement cost was considered for the battery. The lifetime of the batteries is 18 years. In the $18^{\text {th }}$ year it will be necessary to replace the entire battery bank. The present value replacement cost of the battery for the $18^{\text {th }}$ year is US\$7 448. The total LCC for 25 years of lifetime of the system is US\$117 480. These costs are shown in Table 7.

\subsection{Net Present Value}

The financial parameters demonstrate the financial feasibility of this project (Table 8). The positive NPV and IRR greater than the discount rate $(28 \%>10 \%)$ make the implementation of the system attractive for a private investor. Additional costs for the implementation of this project such as engineering, social and environmental consulting were not taken into account. However, these results demonstrate that additional costs are unlikely to render this project financially unviable. The payback period of the project is 4.27 years. The short term payback period increases the attractiveness of a project to financial institutions. 
Table 7. Initial investment cost

\begin{tabular}{llc}
\hline Component & Unit Cost & Total Cost (US\$) \\
\hline PV array & US\$672 per unit & 38304 \\
Battery & US\$0.1475 per kW & 26550 \\
Controller/regulator & US\$600 per kW & 10000 \\
Battery charger & US\$650 per unit & 1300 \\
Other components & $10 \%$ of the main components costs & 7615 \\
Installation cost & $10 \%$ of the total system cost & 8377 \\
Total cost & \multicolumn{1}{c}{-} & 92146 \\
\hline
\end{tabular}

Table 8. Financial parameters

\begin{tabular}{ll}
\hline Parameters & Value \\
\hline LCC (US\$) & 117480 \\
NPV (US\$) & 186918 \\
IRR (\%) & 28 \\
Payback period (years) & 4.27 \\
\hline
\end{tabular}

\subsection{Levelised Cost of Electricity}

Table 9 shows the LCOE of this project to be US\$0.30 per $\mathrm{kWh}_{\mathrm{e}}$. This is lower than the tariff BT8-240 with FOSE which is US\$0.35 per $\mathrm{kWh}_{\mathrm{e}}$. The tariff BT8-240 without the subsidy is US\$1.74 per $\mathrm{kWh}_{\mathrm{e}}$. Initially, this result suggests that fewer subsidies from the government are required to make this project feasible. However, further research is required to confirm this assumption.

Table 9. Levelised Cost of Electricity

\begin{tabular}{ll}
\hline Financial indicator & Value \\
\hline LCC $($ US\$) & 117480 \\
Total electricity supplied $\left(\mathrm{kWh}_{\mathrm{e}}\right)$ & 385217 \\
LCOE supplied $\left(\mathrm{US} \$ / \mathrm{kWh}_{\mathrm{e}}\right)$ & 0.30 \\
\hline
\end{tabular}

\section{Conclusions}

Technical and financial analyses have been carried out for a stand-alone PV system for rural electrification in the Andean South region of Peru. The presented methods of analysis to assess PV mini-grids for rural electrification are replicable for other remote regions. Performance analysis was done using long-term meteorological data from NASA due to unavailability of measured data for the location selected. The NASA data was found to be in agreement with the Solar Atlas of Peru within an acceptable range. In general, the household electricity consumption in the Andean South region is low, which represents a barrier for grid extension and private investment. This study included the implementation of a leisure and health community centre for the productive use of electricity. The community centre represented about $20 \%$ of the total electricity consumption of the project and it improved the financial attractiveness of the project.

The simulations and optimisation, performed by using TRNSYS - GenOpt ${ }^{\circledR}$, demonstrated the feasibility of the project. Based on the current costs of components for the stand-alone PV system, it is technically and financially feasible. The NPV, IRR and payback period results showed that the project is profitable and it represents a medium-term risk horizon for an investor. The result for the LCOE demonstrated that high government subsidies are not required. Overall, this study demonstrated that a stand-alone PV system is a suitable option for rural electrification in the Andean South region of Peru. 


\section{Acknowledgment}

The authors wish to thank A/Prof. Bob Fuller, Infrastructure Engineering, the University of Melbourne for his useful comments, proof reading and correcting the final manuscript.

\section{References}

Alegre, R. (2012). Photovoltaic panels quote, 12 May 2012.

Boonbumroong, U., Pratinthong, N., Thepa, S., Jivacate, C., \& Pridasawas, W. (2011). Particle swarm optimization for AC-coupling stand alone hybrid power systems. Solar Energy, 85(3), 560-569. http://dx.doi.org/10.1016/j.solener.2010.12.027

Branker, K., Pathak, M. J. M., \& Pearce, J. M. (2011). A review of solar photovoltaic levelized cost of electricity. Renewable \& Sustainable Energy Reviews, 15(9), 4470-4482. http://dx.doi.org/10.1016/j.rser.2011.07.104

Cabraal, R. A., Barnes, D. F., \& Agarwal, S. G. (2005). Productive uses of energy for rural development. Annual $\begin{array}{lllll}\text { Review of } & \text { Environment and }\end{array}$ http://dx.doi.org/10.1146/annurev.energy.30.050504.144228

Casillas, C. E., \& Kammen, D. M. (2011). The delivery of low-cost, low-carbon rural energy services. Energy Policy, 39(8), 4520-4528. http://dx.doi.org/10.1016/j.enpol.2011.04.018

Cherni, J. A., \& Preston, F. (2007). Rural electrification under liberal reforms: the case of Peru. Journal of Cleaner Production, 15(2), 143-152. http://dx.doi.org/10.1016/j.jclepro.2006.01.029

DeltaVolt. (2012). Black 300, el Aerogenerador Eficiente. Retrieved May 1, 2012, from http://deltavolt.pe/black300

Dimas, F. A., Gillani, S. I., \& Ans, M. S. (2011). Preliminary Investigation into the use of Solar PV Systems for Residential Application in Bandar Sri Iskandar, Malaysia. Journal of Applied Science 11(11), 2012-2017. http://dx.doi.org/10.3923/jas.2011.2012.2017

Dirección General de Electrificación Rural. (2010). Plan Nacional De Electrificacion Rural (PNER) Periodo 2011 - 2020. Retrieved March 27, 2012, from http://dger.minem.gob.pe/webdger/ArchivosDger/PNER_2011-2020/PNER_2011-2020.pdf

Dirección General de Electrificación Rural. (2012). Plan Nacional de Electrificación Rural en Sistema de Información Geográfica - GIS (2011 - 2020). Retrieved March 27, 2012, from http://dger.minem.gob.pe/pnergis/

Duffie, J. A., \& Beckman, W. A. (2006). Solar Engineering of Thermal Process (3rd ed.). New Jersey, USA: John Wiley \& sons, Inc.

EURO-SOLAR. (2012). Description of the Kit Retrieved April 18, 2012, from http://www.programaeuro-solar.eu/eng/kit.php

Ferrer-Martí, L., Garwood, A., Chiroque, J., Escobar, R., \& Coello, J. C., M. (2010). A community small-scale wind generation project in Peru. Wind Engineering, 34(3), 277-288. http://dx.doi.org/10.1260/0309-524X.34.3.277

Gansler, R. A., Klein, S. A., \& Beckman, W. A. (1994). Assessment of the Accuracy of Generated Meteorological Data for Use in Solar-Energy Simulation Studies. Solar Energy, 53(3), 279-287. http://dx.doi.org/10.1016/0038-092X(94)90634-3

Grainger, W. (1990). Wind and Solar data for sizing small wind turbine and photovoltaic power plants. Solar \& Wind Technology, 7(1), 63-66. http://dx.doi.org/10.1016/0741-983X(90)90013-R

Instituto Nacional de Estadisticas e Informatica. (2007). Censos Nacionales 2007: XI de Población y VI de Vivienda. Retrieved April 12, 2012, from http://censos.inei.gob.pe/censos2007/

Instituto Nacional de Estadisticas e Informatica. (2012). Informacion Economica: Encuesta de Expectativas Macroeconómicas de Inflación. Retrieved May 28, 2012, from http://www.inei.gob.pe/web/aplicaciones/siemweb/index.asp?id=003

International Energy Agency. (2010). Technology Roadmaps: Solar photovoltaic energy. 48. Retrieved from http://www.iea.org/publications/freepublications/publication/name,3902,en.html

International Energy Agency. (2011). World Energy Outlook 2011. Retrieved May 28, 2012, from http://dx.doi.org/10.1787/weo-2011-en 
Kaundinya, D. P., Balachandra, P., \& Ravindranath, N. H. (2009). Grid-connected versus stand-alone energy systems for decentralized power-A review of literature. Renewable \& Sustainable Energy Reviews, 13(8), 2041-2050. http://dx.doi.org/10.1016/j.rser.2009.02.002

Kishore, V. V. N. (2009). Renewable Energy Engineering and Technology: Principles and Practice. New Delhi, India.

Klein, S. A., Beckman, W. A, Mitchell, J. W, Duffie, J. A., Duffie, N. A., Freeman, T. L., ... D. A. (2006). TRNSYS 16 - A TRaNsient SYstem Simulation program, Volume 5, Mathematical Reference. Wisconsin, USA: Solar Energy Laboratory, Univ. of Wisconsin-Madison.

Liders, S. A. C. (2012). Productos de la Empresa: Paneles Solares Monocristalinos. Retrieved April 4, 2012, from http://www.fotovoltaicosperu.com/panelsolar.html

Martinot, E., Chaurey, A., Lew, D., Moreira, J. R., \& Wamukonya, N. (2002). Renewable energy markets in developing countries. Annual Review of Energy and the Environment, 27, 309-348. http://dx.doi.org/10.1146/annurev.energy.27.122001.083444

Mathur, J. K., \& Mathur, D. (2005). Dark homes and smoky hearths: rural electrification and women. Economic and Political Weekly, 40(7), 638-643.

Meier, P., Tuntivate, V., Barnes, D. F., Bogach, S. V., \& Farchy, D. (2010). Peru: National Survey of Rural Household Energy Use. Retrieved May 28, 2012, from https://mail.energypedia.info/images/9/97/ESMAP_PeruNationalSurvey_Web_0.pdf

Ministerio de Energia y Minas. (2012). Guia del Consumo y Facturacion de Energia Electrica Cliente Regulado Bt5 B-Residencial. Retrieved from http://intranet.minem.gob.pe/AppWeb/DGE/CalculoConsumo

Ministerio de Energia y Minas, \& World Bank - Global Environment Fund. (2003). Atlas Eolico de Peru. Retrieved from http://dger.minem.gob.pe/AtlasEolico/AtlasEolicoLibro.asp

Ministerio de Energia y Minas, \& World Bank. (2011). Mejoramiento de la Electrificacion Rural mediante la aplicacion de fondos concursables - FONER II. 238. Retrieved May 28, 2012, from http://dger.minem.gob.pe/Transparencia_ManualesBancoMundial.aspx

Mondal, A. H., \& Denich, M. (2010). Hybrid systems for decentralized power generation in Bangladesh. Energy for Sustainable Development, 14(1), 48-55. http://dx.doi.org/10.1016/j.esd.2010.01.001

Morante, F., \& Zilles, R. (2008). Electric consumption in SHSs in rural communities of brazil and Peru and recommendations for sizing. Progress in Photovoltaics, 16(2), 171-179. http://dx.doi.org/10.1002/Pip.790

National Aeronautics and Space Administration. (2012). Surface meteorology and Solar Energy: A renewable energy resource web site (release 6.0). Retrieved March 1, 2012, from http://eosweb.larc.nasa.gov/sse/

Organismo Supervisor de la Inversion en Energia y Mineria. (2012). Regulacion Tarifaria. Retrieved Jun 4, 2012, from http://www2.osinerg.gob.pe/

Patel, M. (2006). Wind and Solar Power Systems. Design, Analysis and Operation. New York, USA.

ProViento. (2012). ProViento. Retrieved May 1, 2012, from http://www.proviento.com.pe/

Servicio Nacional de Meteorologia e Hidrologia del Peru. (2012). Informacion del Tiempo Clima y Agua. Retrieved March 1, 2012, from http://www.senamhi.gob.pe/

Servicio Nacional de Meteorologia e Hidrologia del Peru, \& Ministerio de Energia y Minas. (2003). Atlas de Energia Solar. Retrieved from http://dger.minem.gob.pe/atlassolar/ATLAS_SOLAR.pdf

Villanueva-Saberbein, K. S. (2012). Stand-alone Photovoltaic and Wind Energy Conversion Systems for Andean South Peru, Master of Environment (Energy Studies) research report, Office of Environmental Programs, the University of Melbourne. p. xiii+75.

Wetter, M. (2008). GenOpt ${ }^{\circledR}$ Generic Optimization Program. User Manual Version 2.1.0.

Williams, A. A., \& Simpson, R. (2009). Pico hydro - Reducing technical risks for rural electrification. Renewable Energy, 34(8), 1986-1991. http://dx.doi.org/10.1016/j.renene.2008.12.011

Yang, H. X., Zhou, W., \& Lou, C. Z. (2009). Optimal design and techno-economic analysis of a hybrid

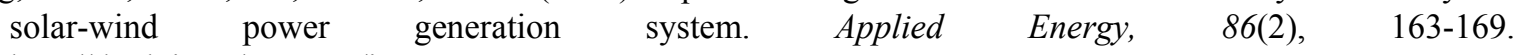
http://dx.doi.org/10.1016/j.apenergy.2008.03.008 
Zhou, W., Lou, C. Z., Li, Z. S., Lu, L., \& Yang, H. X. (2010). Current status of research on optimum sizing of stand-alone hybrid solar-wind power generation systems. Applied Energy, 87(2), 380-389. http://dx.doi.org/10.1016/j.apenergy.2009.08.012 